\title{
The Woman with the Ibo Nose and the Scottish Tongue: Expressions of Belonging and Return in Jackie Kay's Writing
}

La femme au nez ibo dont la langue est écossaise : expressions d'appartenance et de retour dans l'écriture de Jackie Kay

\section{Jane Gray}

\section{(2) OpenEdition Journals}

\section{Electronic version}

URL: https://journals.openedition.org/etudesecossaises/234

DOI: $10.4000 /$ etudesecossaises.234

ISSN: 1969-6337

\section{Publisher}

UGA Éditions/Université Grenoble Alpes

\section{Printed version}

Date of publication: 30 September 2010

Number of pages: $155-168$

ISBN: 978-2-84310-173-1

ISSN: $1240-1439$

\section{Electronic reference}

Jane Gray, "The Woman with the Ibo Nose and the Scottish Tongue: Expressions of Belonging and Return in Jackie Kay's Writing", Études écossaises [Online], 13 | 2010, Online since 30 September 2011, connection on 11 April 2023. URL: http://journals.openedition.org/etudesecossaises/234 ; DOI: https:// doi.org/10.4000/etudesecossaises.234 


\title{
The Woman with the lbo Nose and the Scottish Tongue: Expressions of Belonging and Return in Jackie Kay's Writing
}

\author{
My grandmother is like a Scottish pine, \\ tall, straight-backed, proud and plentiful, \\ a fine head of hair, greying now \\ tied up in a loose bun. \\ Her face is a ploughed land. \\ Her eyes shine rough as amethysts. \\ She wears a plaid shawl \\ of our clan with the zeal of an Amazon. \\ She is one of those women \\ burnt in her croft rather than moved off the land. \\ She comes from them, her snake's skin. \\ She speaks Gaelic mostly, English only \\ when she has to, then it's blasphemy. \\ My grandmother sits by the fire and swears \\ There'll be no darkie baby in this house \\ My grandmother is a Scottish pine, \\ tall, straight-backed proud and plentiful, \\ her hair tied with pins in a ball of steel wool. \\ Her face is tight as ice \\ and her eyes are amethysts. ${ }^{1}$
}

Originally published in 1991, in the now out-of-print collection entitled That Distance Apart, "My Grandmother" was reprinted in Kay's collection of new and selected poems entitled Darling (2007). By way of introduction, this poem will serve to outline some of the themes I wish to develop in relation to the expressions of belonging and return in Jackie Kay's writing.

1. J. Kay, Darling: New and Selected Poems, Northumberland, Bloodaxe, 2007, p. 12. 
First of all, since Kay is an adopted child of Scottish/Nigerian descent, brought up by a white Glaswegian couple, the poem hints at the autobiographical nature of much of Kay's work. But although personal experience informs her writing, Kay is interested in exploring the threshold between fact and fiction, between reality and imagination, creating, rather, out of her own experience. The poem "My Grandmother" illustrates this point, since the grandmother being described can only be a product of the imagination, the reader having been led to understand that the poetic persona is the "darkie baby" in question, verbally banished from the family home before it was even born. Leading on from this idea is the question of identity, of the need to know one's origins, the importance of affiliation, of belonging to a particular place, of knowing where one's home is. This resolutely Scottish grandmother is inextricably linked to her land, to her home, to her language and to her origins. However, following her blatant racist declaration - pronounced almost as a statement of high moral principle - the protagonist proceeds to distort these images, the balladtype refrain thus hinting at a somewhat ambivalent vision of Scotland and its people.

It also alludes to another of Kay's thematic preoccupations: the notion of "Blackness" in contemporary Britain, exploring issues of divided identity, hybridity, home and exile, loss and longing. Placed as it is at the opening of the Darling collection, the poem appears almost as a prologue to The Adoption Papers, which immediately follows it, and could be seen, therefore, as the starting point of an imaginary poetic journey undertaken by Kay to retrace her origins, and find her home(s). The aim of this paper is therefore to analyse - by focussing on a selection of Kay's poetry and prose - how the writer comes to terms with these questions of identity, home and belonging, and more significantly, how the theme of return to her African origins is expressed in her work.

Many of the interviews that Kay has given over the years highlight the way in which she draws on her personal experience of being Black and Scottish as creative inspiration for her poetry. Kay describes this position as having been unusual when growing up; a contradictory state of being in which she felt isolated. She refers to having been subjected to racist abuse as a teenager, which led her to begin writing "revenge poems". ${ }^{2}$ In other words, the powerful tool of the imagination - which was perhaps initially considered to be "therapeutic" - developed into a means for Kay to create images for herself, to define a space she could be at home with,

2. Jackie Kay expressed these feelings during a radio interview with Eleanor Wachtel aired on 7 October 2007 on the Canadian programme Writers and Company, <www.cbc.ca/wordsatlarge/ blog/2008/08/eleanor_wachtel_talks_with_poe.html>. 
to which she could belong. Of course, even if the "revenge poems" of her youth are no longer part of her poetic agenda, she has continued to express a double relationship to her country of birth as well as an ambivalent sense of belonging. This is illustrated in several of her poems and short stories: "So You Think I'm A Mule" (A Dangerous Knowing, 1988), "In My Country" (Other Lovers, 1993), "The Broons' Bairn's Black" (Off Colour, 1998), or "The Oldest Woman in Scotland" (Why Don't You Stop Talking, 2002), to name but a few examples. An incident Jackie Kay actually experienced is poetically expressed in "So You Think I'm A Mule". ${ }^{3}$ Kay describes in an interview with Rebecca Wilson how a woman approached her and questioned her Scottish identity, insisting: "You're not pure, are you? You're a mulatto." 4 The opening lines read:

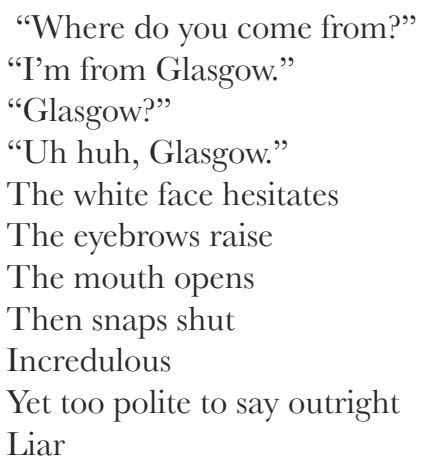

The woman insists on obtaining a more satisfactory answer to comfort her suspicions, until she utters the fatal word "mulatto", resulting in a fierce poetic diatribe, the use of alliteration insisting on the "dialectics of mixtures" that the speaker finds so insulting:

Listen. My original father was Nigerian

to help with your confusion

but hold on right there

If you dare mutter mulatto

Hover around hybrid

Hobble on half-caste

And intellectualize on the

"mixed race problem",

I have to tell you:

3. Jackie Kay, "So You Think I'm a Mule?", in A Dangerous Knowing: Four Black Women Poets, London, Sheba Feminist Publishers, 1988.

4. R. Wilson and G. Somerville-Arjat (eds), Sleeping With Monsters: Conversations with Scottish and Irish Women Poets, Edinburgh, Polygon, 1990, p. 121. 
Take your beady eyes offa my skin;

Don't concern yourself with

The "dialectics of mixtures";

Don't pull that strange blood crap

On me Great White Mother

The concluding lines allude to the question of "belonging", and the speaker proceeds to take on a feminist stance and identify herself politically with other women of the Black diaspora:

So take your questions, your interest,

Your patronage. Run along.

Just leave me.

I'm going to my Black sisters

To women who nourish each other

On belonging

There's a lot of us

Black women trying to define

Just who we are

Where we belong

And if we know no home

We know one thing:

We are Black

We're at home with that.

These lines become problematic, however, when they are considered in relation to the place - Glasgow - the speaker initially identifies herself with, since it suggests that a sense of belonging can only be found elsewhere. The statement: "I'm going to my Black sisters" thus implies a form of exile - be it geographical or imaginary, forced or voluntaryfrom Scotland.

The purpose of this paper is by no means to question racism in Scottish society, and indeed, I would tend to agree with Gavin Miller's assertion-borrowing from Walter Benn Michaels - that "even when we are racist, the society to which we are committed is not". ${ }^{5}$ However, this feeling of being a "contradiction", or an "anomaly" (SWM, p. 121) - to quote some of the words used by the poet herself - is echoed in other examples of how Black or Asian Scots negotiate with the idea of Scottishness. In 2002, Tom Devine and Paddy Logue brought together the reflec-

5. W. B. Michaels, The Trouble with Diversity: How We Learned to Love Identity and Ignore Equality, New York, Metropolitan, 2006, pp. 82-3, in G. Miller, "Scotland's Authentic Plurality: The New Essentialism in Scottish Studies", Scottish Literary Review, vol. 1, no. 1, Spring/Summer 2009, p. 168. 
tions of what they described as a "balanced cross-section of Scots" 6 into a book entitled Being Scottish: Personal Reflections on Being Scottish Today. The accounts given by Robina Qureshi (born and brought up in Glasgow to Pakistani immigrants) and Mukami McCrum (born in Kenya and Chief Executive of Central Scotland Racial Equality Council), reiterate - to varying degrees - Kay's preoccupations with belonging within a Scottish context. Mukami McCrum's contribution is particularly interesting in that she notes parallels between the Scots and the people of Unjiru where she grew up. However, brought up in the Church of Scotland tradition in Kenya, she writes:

For me, being Scottish is about a sense of belonging, identity and how others see me. While Kenyans often remind me that I am Scottish, not all Scots have come to terms with my colour and ethnic background. When I say that I come from Linlithgow, political correctness makes some people accept it, while others ask me, where do you really come from [...] My Scottish teachers in Kenya never told us about the inherent fear and dislike that some Scots have for people like me. [...] Clearly my colour and being Scottish were mutually exclusive and a challenge for many people. (BS, pp. 156-7.)

Robina Qureshi's contribution is conveyed with much more anger. Both personal experience and her active involvement in Scotland in challenging institutionalised racism and government policy towards refugees lead her to describe Scottish society as "deeply racist" (BS, p. 219) and one in which the refrains: "Go back home, Paki', 'Go back to where you belong" (BS, p. 218) that she heard in her childhood perhaps too many times for comfort, make it difficult for her to "feel Scottish". She writes:

I don't really feel Scottish unless I go abroad, but then I say "I am from Scotland", not "I'm Scottish". No way, not unless it is to annoy the hell out of someone who is determined that I don't come from here. Scotland is not my home in that sense of the word... (BS, p. 218.)

Even though we must bear in mind - as do the editors of the book in which these accounts were published - that these examples are but "one snapshot of Scottish identity" (BS, p. XIII), they do tend to highlight a common sense of alienation and a difficulty in finding a "home". In Jackie Kay's case, though, and in the case of writers such as the late Maud Sulter, or "New Scots" such as Leila Aboulela or Imtiaz Dharker, this particular position has been a continuing source of creative tension.

6. T. Devine and P. Logue (eds), Being Scottish: Personal Reflections on Scottish Identity Today, Edinburgh, Polygon, 2002, p. XII. 
Kay's White Scottish upbringing adds a further dimension to her writing. Having been "steeped in Scottish culture" (SWM, p. 122), she claims that:

If you're brought up in a place, you get that identity very, very fixedly. And you don't necessarily get a sense of your being Black, because there's nothing else around you affirming that you are. (SWM, p. 122.)

The poem "Watching People Sing" (Other Lovers, 1993), illustrates this point particularly well. It evokes a family gathering, during which the persona's relatives take turns to demonstrate their singing talents. The titles and lyrics from traditional Scottish ballads, which punctuate this poem, serve, as Alison Lumsden suggests, to:

[...] provide the singers with a link to "The mouths of the people of the past", who offer the speaker both a context in which she may belong, and the possibility of a future grounded in that context. ${ }^{7}$

Furthermore, Alison Lumsden suggests that such "an overtly Scottish poem" (CSWW, p. 84) as this one immediately following her sequence of "Bessie Smith" poems (Other Lovers) - which engage in expressions of Black identity - serves to "de-stabilise" any implication that "blackness may be a more important aspect of identity for the poet" ${ }^{C S W W W}$, p. 84). The different sequences in Kay's poetry do tend to juxtapose these themes and can be interpreted as a means of further highlighting the poet's artistic negotiation with being both Black and Scottish, of belonging to two cultures, as it is expressed elsewhere in her work. Music is another device the poet uses to convey this state of being. Both ballad and jazz music thematically, stylistically and rhythmically punctuate Kay's writing and serve as a way, she says, "of being Black and being Scottish at the same time in words". ${ }^{8}$

Hence, the juxtaposition of themes in Kay's collections may serve rather to define a space in which one's identity can be both one and the other, both "Kail" and "Callaloo" as Kay's poem of the same name suggests, a place where it is possible to be an "Afro-Scot" or a "Celtic-AfroCaribbean", where you can "dance a reel and a salsa/remember Fannie Lou Hamer and Robert Burns" (my italics). ${ }^{9}$

7. A. Lumsden, in A. Christianson and A. Lumsden (eds), Contemporary Scottish Women Writers, Edinburgh, Edinburgh University Press, 2000, p. 84.

8. Jackie Kay interviewed for The Poetry Archive, <www.poetryarchive.org>.

9. J. Kay, "Kail and Callaloo", in S. Grewal, J. Kay, L. Landor, G. Lewis, and P. Parmar (eds), Charting the Fourney: Writings by Black and Third World Women, London, Sheba Feminist Publishers, 1988, p. 195. 
We may also suggest that, as a writer who has now been living in England since the 1980s, her "overtly Scottish" poems may be seen as a way to reconnect with her Scottish origins, in the same way as poets or writers such as John Burnside or Carol Ann Duffy have done. Distance, according to Kay, has given her "an outside way of looking back in". ${ }^{10}$ She has stated in interviews that moving to England has given her more confidence and courage as a lesbian writer (SWM, pp. 126-7). She also explains that the more "multi-cultural" nature of Manchester (where she now lives) was important for her because she did not want her son to be "quizzed permanently about his identity". ${ }^{11}$ Although these remarks hint at the complex "double" relationship Kay has with Scotland, some of her work echoes the recurring themes of loss and (be)longing, of displacement and of return in relation to Scotland that can be found in Burnside's "Exile's Return" (Dream State, p. 9) ${ }^{12}$ and "Out of Exile" (ibid.), or in Carol Ann Duffy's poems "Originally", "Plainsong" and "The Way My Mother Speaks" for example. In Duffy's poem "Originally" 13 , the protagonist's expression of exile is reminiscent of Edward Said's description of "estrangement", as that "unhealable rift forced between a human being and a native place, between the self and its true home". ${ }^{14}$ The opening lines read:

We came from our own country in a red room which fell through the fields, our mother singing our father's name to the turn of the wheels. My brothers cried, one of them bawling Home, Home, as the miles rushed back to the city, the street, the house, the vacant rooms where we didn't live any more.

To the physical, geographical displacement is added linguistic alienation, reminding the speaker that she does not belong, because her accent is "wrong". Then follows the expression of sadness and longing as the speaker cries: "I want our own country." The concluding lines evoke the role of memory, as "you forget, or don't recall, or change":

I remember my tongue

shedding its skin like a snake, my voice

10. In L. Brooks, "Don't tell me who I am", The Guardian, 12-01-2002, [online edition].

11. Interview with Eleanor Wachtel, op. cit.

12. D. O'Rourke (ed.), Dream State: The New Scottish Poets, Edinburgh, Polygon, 1994, 231 p.

13. C. A. Duffy, "Originally" (1990), in Selected Poems: Carol Ann Duffy, London, Penguin Books, 1994, p. 65.

14. E. Said, "Reflections on Exile", in Reflections on Exile and Other Essays, Harvard University Press, 2000, p. 173. 
in the classroom sounding just like the rest. Do I only

think

I lost a river, culture, speech, sense of first space

and the right place? Now, Where do you come from?

strangers ask. Originally? And I hesitate.

As memory fades through time, there is an inherent sense of something irretrievably lost which is much more than just an accent or a place: it is - as Margery Palmer McCulloch has suggested in reference to this poem - a progressive loss of the self ${ }^{15}$, made all the more painful by the protagonist's awareness of it. These sentiments of loss of Scottish accent through exile as synonymous with the loss of the "self" are reiterated in Kay's poem, "Old Tongue"16.

When I was eight, I was forced south.

Not long after, when I opened

my mouth, a strange thing happened.

I lost my Scottish accent.

Words fell off my tongue:

eedyit, dreich, wabbit, crabbit

stummer, teuchter, heidbanger,

so you are, so am ur, see you, see ma ma,

shut yer geggie or I'll gie you the malkie!

My own vowels started to stretch like my bones

and I turned my back on Scotland.

Words disappeared in the dead of night, new words marched in: ghastly, awful, quite dreadful, scones said like stones.

Pokey hats into ice cream cones.

Oh where did all my words go-

my old words, my lost words?

Did you ever feel sad when you lost a word,

did you ever try and call it back

like calling in the sea?

If I could have found my words wandering,

I swear I would have taken them in,

swallowed them whole, knocked them back.

Out in the English soil, my old words

buried themselves. It made my mother's blood boil.

15. M. P. McCulloch, "Scottish Women's Poetry 1972-1999: Transforming Traditions", in

A. Christianson and A. Lumsden, Contemporary Scottish Women Writers, p. 21.

16. J. Kay, "Old Tongue", in Life Mask, Northumberland, Bloodaxe, 2005, p. 50. 
I wanted them back; I wanted my old accent back, my old tongue. My dour soor Scottish tongue.

Sing-songy. I wanted to gie it laldie.

Again we have the use of the metonymical, melopoeic Scottish "tongue" as bearer of the "self", as well as the emotions of sadness and longing induced by the experience of loss. It is interesting to note the reference to the mother in this context, who serves to remind the protagonist of his/her origins; of the "mother tongue". The same idea is conveyed in Carol Ann Duffy's poem entitled "The Way My Mother Speaks". ${ }^{17}$ The persona takes the train back down to England after a visit "home", repeating throughout the duration of the journey her mother's characteristically Scottish syntax in the expression: "What like is it", and concluding: "I am homesick, free, in love / with the way my mother speaks."

For Jackie Kay, therefore, themes characteristic of displacement permeate her work in a similar way. But as we have seen, there are constant reminders that "home" is also to be found elsewhere, either through the refusal of others to acknowledge her Scottish identity due to the colour of her skin, or through her own awareness of her being an adopted child of African descent. Brought up by White Scottish parents, Kay has said that as a child, she "never had any sense of Black culture at all, until (she) went about finding and creating it for (her)self" (SWM, p. 122). In one interview she relates with humour to having created an "imaginary Black family" in the jazz and blues singers Bessie Smith, Duke Ellington, Count Basie or Sarah Vaughan, "in the absence of having Black neighbours or Black friends". 18 This "extended family" — as it were - implies the possibility of being "someone else", and is creatively expressed in her poetry and prose alike. In the poem "The Red Graveyard" 19 the speaker recalls visual memories of her childhood home, and of her father dancing to Bessie Smith, and wonders: "Why do I remember her voice [...]. Why do I remember the blues?" In her sequence "The Adoption Papers", which tells the story of adoption through the voices of the biological mother, the adoptive mother and the daughter, the daughter finds self-recognition in the African-American jazz artists Pearl Bailey and Bessie Smith and in human rights activist Angela Davis. Kissing the poster of Angela Davis she has on her bedroom wall, the girl reflects upon their skin colour:

17. C. A. Duffy, Selected Poems, p. 88.

18. Interview with Eleanor Wachtel, op. cit.

19. J. Kay, "The Red Graveyard" (Other Lovers, 1993), in Darling: New E̊ Selected Poems, p. 73. 
I can see my skin is that colour

but most of the time I forget,

so sometimes when I look in the mirror

I give myself a bit of a shock

and say to myself Do you really look like this?

as if I'm somebody else. I wonder if she does that. ${ }^{20}$

In the same way, the poetic persona in "Somebody Else" laments: "It's no laughing matter going about the place / all the time being somebody else: / people mistake you; you mistake yourself." ${ }^{21}$ This theme is also at work in the novel Trumpet, the story of a famous Black Scottish trumpet player, Joss Moody, who after his death is revealed to have been a woman. His adopted son, Colman, is deeply upset at this revelation, and begins questioning his own identity, and the possibility of being someone completely different, had he not been adopted. Reflecting on his original name, he claims:

If I'd stayed William Dunsmore all my life I'd have been a completely different man. Definitely. I mean a William Dunsmore smile would be different from a Colman Moody's smile. All my facial expressions would have been different. I bet even my walk would have been heavier if I'd have been William Dunsmore. Heavy-footed. Maybe a bit lopsided. ${ }^{22}$

Finally, and perhaps even more significantly, the poem "Pride" 23 which tells of a chance encounter between a Black woman and a Black man on a train - evokes an imaginary return to the woman's African origins when the man recognizes the features of the Ibo people on her face. As the man excitedly claims: "That nose is an Ibo nose. / Those teeth are Ibo teeth", the speaker says: "There was a moment when / my whole face changed into a map, / and the stranger on the train / located even the name / of my village in Nigeria / in the lower part of my jaw." As their conversation develops, the woman imagines her return to this other "home":

I saw myself arriving

the hot dust, the red road,

the trees heavy with other fruits,

the bright things, the flowers.

I saw myself watching

20. J. Kay, The Adoption Papers, Northumberland, Bloodaxe, 1991, p. 27.

21. J. Kay, "Somebody Else", in Off Colour, Northumberland, Bloodaxe, 1998, p. 27.

22. J. Kay, Trumpet, London, Picador, 1998, p. 56.

23. J. Kay, "Pride", in Off Colour, p. 62. 
the old people dance towards me

dressed up for me in happy prints.

And I found my feet.

I started to dance.

I danced a dance I never knew I knew.

Words and sounds fell out of my mouth like seeds.

I astonished myself.

My grandmother was like me exactly, only darker.

When I looked up, the black man had gone.

Only my own face startled me in the dark train window.

What is significant at this point is the vagueness of the African imagery the woman conjures up. She evokes "other fruit", "bright things", "happy prints", "a dance", "words" and "sounds", alluding to the oneiric quality of her return to Africa but at the same time reflecting Koye Oyedeji's claim that "for many of a Black generation born in Britain, a knowledge of Africa remains no more than facing The Unexamined River. A rippling river across which you can see Africans on the other side". ${ }^{24}$ Colman Moody in Trumpet alludes to this notion of a "fantasy" Africa as opposed to a "real" Africa:

We never actually got to go to Africa. Joss had built up such a strong imaginary landscape within himself that he said it would affect his music to go to the real Africa. Every Black person has a fantasy Africa, he'd say. Black British people, Black Americans, Black Caribbeans, they all have a fantasy Africa. It's all in the head. (T, p. 34.)

Nigerian academic Afam Akeh - who considers Jackie Kay as a writer of the "African" diaspora - asserts that such writers' "representations of home" (i.e. Africa):

remain poignantly estranged, as they focus, like tourists, on what is strange, what is different, what might elicit laughter, disgust or some other strong interest or response from outsiders about that distant location or memory they interpret as home. ${ }^{25}$

24. K. Oyedeji, "Prelude to a Brand New Purchase on Black Political Identity: A Reading of Bernadine Evaristo's Lara and Diran Adebayo's Some Kind of Black", in K. Sesay (ed.), Write Black Write British: From Post Colonial to Black British Literature, Hertford, Hansib Publications, 2005, p. 355.

25. A. Akeh, "Poor' African Writers Travelling: Home and Exile in Younger Nigerian Diasporic Writing", in Sentinel Poetry, no. 48, November 2006 [online journal], <www.sentinelpoetry.org.uk/ 1106/Afam_Akeh.html>. 
He insists on "the diasporic personal experiences of these 'African' writers as being influential in 'how they write, (and) what they write". ${ }^{26}$ For Jackie Kay, in "the absence of an intimate knowledge of the material realities of Africa", ${ }^{27}$ the sequence of African poems published in the collection Life Mask comprises a fusing and juxtaposition of reality and the imagination pertaining to magic realism, intertwining her personal experience of travelling to Nigeria to meet her birth father with African myths, stories, rituals and masks, landscapes, and animal and food imagery. This imagery provides the backdrop for dream-like journeys along the "hot dust, red $\operatorname{road}(\mathrm{s})$ " ${ }^{28}$ — a recurring image in Kay's work - as the protagonist negotiates with finding a sense of belonging in her father's country in poems such as "Things Fall Apart", "A White African Dress" or "Kano", for example. Brenda Cooper, in her analysis of the works of diasporic women writers of African background, sees this "excavating" of African stories and beliefs as a way of "stak[ing] a claim [...] to Africa". ${ }^{29}$ However, she sees their use of magic realism as "stretched taut, given that they have had neither first hand experience of the supernatural world of the African oral tradition, nor of the material cultural background of their [...] African parents". ${ }^{30}$ This is not to undermine the legitimacy of their African-inflected writing, but rather to insist on the way that such writers - including Jackie Kay - use it to represent their personal experience of being between two cultures. Gina Wisher refers to Jackie Kay along with Monica Ali (Brick Lane) and Zadie Smith (White Teeth) as being among UK Asian and Black writers who:

negotiate potential and real difficulties of working within the diaspora, developing and articulating a hybrid existence and identity, charting passages between cultures and between their perceptions of those within and without their own communities. ${ }^{31}$

Jackie Kay's creative "return" to her African roots has also led to poetic expressions of Britain's colonial past, lending a voice to those who suffered enslavement or racial intolerance. This can be seen in poems from the collection Off Colour such as "Hottentot Venus" or "Gambia",

\section{Ibidem.}

27. B. Cooper, "Birthed in the Third Space': Myth and Language in Diasporic Women Writers of African Background" [online], University of Pittsburgh, August 2006, p. 13, <www.english.pitt. edu/.../Cooper\%20--\%20African \%20Novels\%20paper.pdf>.

28. J. Kay, "Kano" (Life Mask), in Darling, p. 180.

29. B. Cooper, op. cit., p. 1.

30. Ibid., p. 13.

31. G. Wisher, "Negotiating passages: Asian and Black Women's Writing in Britain", 2004-05-01, Hecate publication [online article], p. 16. 
for example, or from a specifically Scottish perspective in "Christian Sanderson", the story of a Black Scotswoman deported to Australia after poverty and hunger drove her to steal "sixteen shillings". ${ }^{32}$

In 2007 Kay published the dramatised epic poem The Lamplighter, the multi-vocal story of slavery focussing on the lives of four women. Based on original accounts and testimonies, it bears witness to the horrific pain and suffering felt by those people forced from their lands onto ships and taken to the Caribbean plantations or to Britain to build the industrial cities of Glasgow, Liverpool or Bristol. The women's autodiegetic narratives overlap one another, individual accounts thus fusing together to recount the experience of an entire people. The expression of loss pervades the poem: "I lost my family. I lost my name. / I lost my country. I lost my freedom. I lost my weight. / I lost my sense of smell. [...] I lost my bearings. I lost faith / (for a while.) / I lost my words. / I lost my tongue. / I lost my sense of fun." 33 Memory, home and belonging are leitmotifs in the opening pages as the women recall images, smells and tastes from their "own country" ( $L$, p. 24). But as the poem progresses, these images are replaced by the terrible reality of slavery. The will to return home, however, remains constant, and is symbolically rendered by the Negro spirituals that punctuate the monologues or by the accounts of relentless - albeit vain - attempts to escape. They are given new names: "Constance", thus named so that she "would forever be constant" (L, p. 33); "Black Harriot": "So that white Harriot / Never needed to be called / White Harriot / And could just be Harriot" (L, p. 34). As for "Mary MacDonald", we read: "Original meaning uncertain" (L, p. 33). The "uncertain" origin of this final name appears of course highly ironic, alluding possibly to the poet's criticism of Scotland's problematic lack of acknowledgement of its forebears' role in the slave trade. In an article published in The Guardian, Kay writes:

Being African and Scottish, I'd taken comfort in the notion that Scotland was not nearly as implicated in the horrors of the slave trade as England. [...] Scotland is a canny nation when it comes to remembering and forgetting. The plantation owner is never wearing a kilt. ${ }^{34}$

The Lamplighter was a commissioned work written to mark the 200th anniversary of abolition. Although no city is spared, there is an insistence on how Scotland profited from the triangular slave trade in the slaves' singing in unison of the words "I belong to Glasgow" and "Glasgow belongs

32. J. Kay, Off Colour, p. 29.

33. J. Kay, The Lamplighter, Northumberland, Bloodaxe, 2008, p. 18.

34. J. Kay, "Missing Faces", The Guardian, 2007-03-24 [online article]. 
to me" ( $L$, p. 74), claiming the rightful acknowledgement of their part in building this city, in putting Glasgow "on the map" ( $L$, p. 72$)$. Glasgow streets named after Caribbean islands and tobacco lords are evoked as are the "one hundred Black people / Called MacDonald" on the "slave island of Jamaica" ( $L$, p. 81). Having been repeatedly raped by a Scottish slave owner, Black Harriot claims: "My daughters have Scottish blood. Scotland has my blood" (L, p. 81).

Kay has written about her personal experience of writing this piece of work. Reluctant at first to embark on such a project, which she feared would "pigeonhole" her as a Black writer, she finally accepted, having become aware of her ignorance on the subject through "the shocking original testimonies" 35 she discovered during her research. The actual writing process, she explains, "felt as if I was writing a love letter to my ancestors". 36

Once again, therefore, we witness in Kay's writing a conscious effort to negotiate "passages between cultures and histories", ${ }^{37}$ creatively bringing forth - through this highly symbolic return to Africa's tragic past and Scotland's shameful role in slavery - connections between the two countries. Thus, through her poetry and prose, through the poetic expression of her belonging both to Scotland and Africa, and above all through the juxtaposition of imagery and experiences related to both cultures, I have tried to illustrate how Kay manages to come to terms with what she has described as the "multiplicity" 38 of her own identity. Like other Black British writers, one might argue that she has sought to define a new space: a 'third space'39_to borrow Homi Bhabha's terms - one in which she might feel at home.

\footnotetext{
35. Ibidem.

36. Ibid.

37. G. Wisher, op. cit., p. 4 .

38. In C. Whyte (ed.), Gendering the Nation, Edinburgh, Edinburgh University Press, 1995, p. 10.

39. Homi Bhabha refers to the notion of cultural "hybridity" as the "third space", which "gives rise to something different, something new and unrecognisable, a new area of negotiation of meaning and representation". It is defined as a space "which enables other positions to emerge". See J. Rutherford, "The Third Space. Interview with Homi Bhabha" [online], in Ders. (Hg), Identity: Community, Culture, Difference, London, Lawrence and Wishart, 1990, p. 211, <ccfi.educ.ubc.ca/ Courses_Reading_Materials/ccfi502/Bhabha.pdf>.
} 